\title{
MichAL SigRON
}

Higher Studies of Israel

\section{'INQUIRY PHYSICS' PROGRAM FOR STUDENTS - IMPLEMENTATION OF INQUIRY LEARNING IN THE PHYSICS LESSONS IN THE HIGH SCHOOL IN ISRAEL}

\begin{abstract}
Aвstract. Sigron Michal, 'Inquiry Physics' Program for Students-Implementation of Inquiry Learning in the Physics Lessons in the High School in Israel [Program nauczania fizyki oparty na samodzielnych poszukiwaniach jako przykład tego rodzaju nauczania w izraelskiej szkole średniej]. Studia Edukacyjne nr 45, 2017, Poznań 2017, pp. 387-402. Adam Mickiewicz University Press. ISSN 1233-6688. DOI: 10.14746/ se.2017.45.25

Teaching of the Sciences recently emphasizes more than in the past the importance of the student's experience in inquiry, in different places in the world in general and in Israel in particular. This article describes the process of scientific inquiry and the change of the perception of the role, both of the student and of the traditional teacher, in the performance of the inquiry process. The article presents different initiatives that integrate the learning of inquiry in the teaching of physics in the high school in Israel. These initiatives show that the inquiry laboratories have the potential to promote meaningful learning among the students, to increase the depth of their understanding of the scientific concepts and the understanding of the nature of science. The article focuses on 'Inquiry Physics' program for students and presents the goals, the target audience, the time framework, and the structure of this program. The program aims to assemble the different initiatives under one framework and to provide them with an appropriate place in the teaching of physics. The learning method of inquiry is now fledgling in the State of Israel and mainly in the knowledge realm of physics. Therefore, exposure to this program may contribute to the body of knowledge on the characteristics of learning and teaching through inquiry in general and on the teaching of physics in particular.
\end{abstract}

Key words: inquiry learning, physics inquiry

\section{Introduction}

In recent years, attempts have been made to teach science with greater emphasis than in the past on inquiry learning and the student's experience in 
inquiry, in different places in the world in general ${ }^{1}$ and in Israel in particular. ${ }^{2}$ In Israel a gap has been created between the declarations on the importance of the teaching of inquiry and the implementation of the teaching in practice. Learning and teaching through inquiry is prevalent in the educational system in Israel, and it would seem that it is known and familiar. However, students and teachers who work in the inquiry approach report many difficulties and frustrations. Frequently the school adopts external indications of inquiry (such as submitting a work) and neglects the more essential characteristics of the inquiry (such as the learner is active in the building of his knowledge, creates insights in a variety of thinking strategies). Consequently, the main goal of the learning is distorted. In other words, most of the in-depth components of the inquiry learning have been given up and inquiry has a small part in the teaching, despite the agreement among researchers in the teaching of the sciences and teachers on the importance of inquiry and inquiry skills. ${ }^{3}$

This article describes the process of scientific inquiry and focuses on 'Inquiry Physics' program for students in the Davidson Institute of Science Education in Israel. The article presents the rationale, the goals, the target audience and the structure of this program. The purpose of this article is to expose the 'Inquiry Physics' program. Exposure to this program may contribute to the knowledge existing today on the characteristics of learning and teaching through inquiry in general and on the teaching of physics in particular, with the aim of promoting the inquiry learning in the teaching of physics.

\section{The Process of Scientific Inquiry}

The process of scientific inquiry is a process that requires on the one hand the in-depth understanding of the scientific topic and on the other hand the understanding and ability of analysis of a constellation of data obtained fol-

${ }^{1}$ J. Krajcik et al., Instructional, curricular, and technological supports for inquiry in science classrooms, [in:] Inquiring into Inquiry Learning and Teaching in Science, Eds. J. Minstrell, E.H. Van Zee, Washington, DC 2000, p. 283-315; National Research Council, National Science Education Standards, Washington, DC 1996.

${ }^{2}$ Z. Kapach, From Laboratory Teaching in the Cookbook Approach to Laboratory Teaching in the Inquiry-Based Approach in the Studies of Physics in the High School: Professional Development of Teachers, Rechovot 2015. (Hebrew); Pedagogical Secretary, The Assimilation of Inquiry in the Educational System in Israel, Jerusalem 2008, (Hebrew), http://cms.education.gov.il/EducationCMS/ Units/Mazkirut_Pedagogit/OfekPedagogi/Lemida_Cheker/; A. Hofstein et al., Learning through inquiry in the chemistry laboratory, [in:] Learning through Inquiry, Ed. A. Zohar, Jerusalem 2007. (Hebrew)

3 A. Zohar, Inquiry learning, high thinking skills, and meta-cognition, [in:] Learning through Inquiry: A Continuous Challenge, Ed. A. Zohar, Jerusalem 2007, p. 57-84. (Hebrew) 
lowing the inquiry process. Therefore, the engagement in inquiry requires reference to the two components.

1. Substantive understanding. This includes the meaning and nature of the field of knowledge. This part addresses the contents, main ideas, laws, principles, and theories related to the researched topic. The teaching of the corpus of knowledge, which focuses on knowledge, facts, and theories, is obvious, learned, and expressed in the curricula and textbooks.

2. Procedural understanding. This addresses the way in which the information is collected, analyzed, examined, and interpreted. The teaching of procedure is related more to the development of skills that will allow the student to cope with the way of data collection, organization, and analysis in a meaningful manner. The procedure is the action strategy of the scientist, which also includes the ideological basis for the scientific proofs. To examine a scientific proof, it is important to understand the way in which the information is collected, how it is analyzed, and to what extent it is reliable and valid. The teaching of the procedure is neglected relative to the teaching of the body of knowledge. ${ }^{4}$

The researchers Gott and Duggan ${ }^{5}$ and Roberts ${ }^{6}$ built a model in which the relationship between information and teaching sciences is re-examined. The starting point of this model is that scientific thinking is coping with a problem when the way to solve it is inclusive and leads to the examination of the entirety of the data.

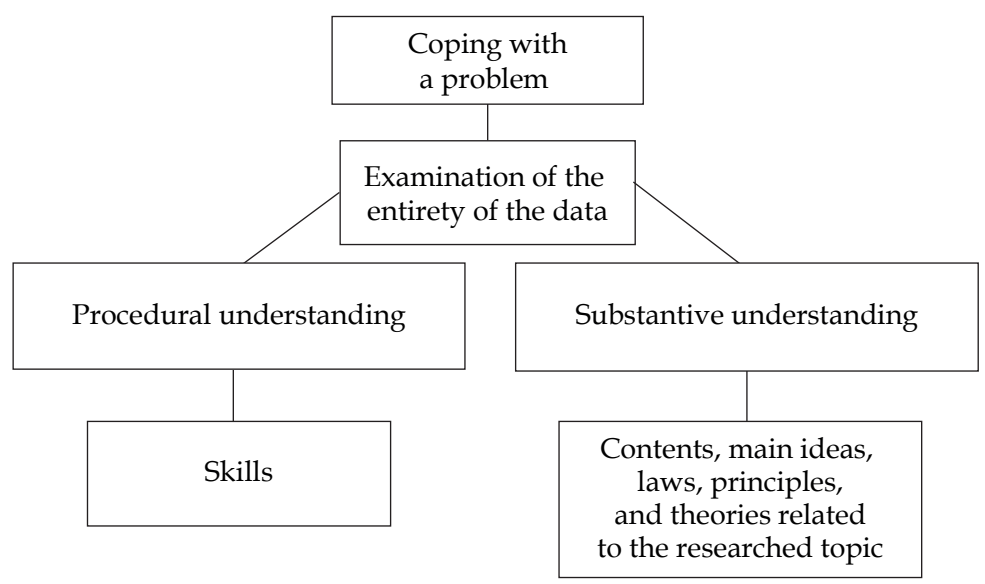

${ }^{4}$ R. Gott, S. Duggan, Investigative Work in the Science Curriculum, Buckingham 1995; R. Roberts, Procedural understanding in biology: "Thinking behind the doing", Journal of Biological Education 2001, 35(3), p. 113-117.

${ }^{5}$ R. Gott, S. Duggan, Investigative Work in the Science Curriculum.

${ }^{6}$ R. Roberts, Procedural understanding in biology, p. 113-117. 
The implementation of this model in the field of the teaching of the sciences means that in the teaching of the sciences it is necessary to address the two components: on the one hand, the understanding of the contents and on the other hand the understanding of the methods through which different scientific questions are examined. Moreover, it is necessary to strive that equal weight is given to the two components: teaching aimed at the understanding of the body of knowledge, teaching aimed at the understanding of the procedure. In other words, the process, which is in essence the actions of the scientist on his way to cope with problems, is no less important than the acquisition of a corpus of knowledge. ${ }^{7}$ It is important to emphasize that the integration of the scientific inquiry process in teaching does not put the processes instead of the contents. The inquiry emphasizes the processes to go into greater depth in the contents and to make them into knowledge that is meaningful for the learner. ${ }^{8}$

The process of scientific inquiry includes a number of main and necessary components, such as, for example, those detailed in the document 'Assimilation of the Degree of Inquiry in the Educational System in Israel ${ }^{\prime 9}$ and from articles. ${ }^{10}$ The components of scientific inquiry are:

- Choice of the topic - identification of the problem/phenomenon and recognition of the background (existing knowledge).

- Asking questions and asking inquiry questions.

- Positing a hypothesis.

- Inquiry constellation - process of the planning and performance of the way of the inquiry action (such as planning and performance of an experiment or observation).

- Processing the findings - treatment and organization of the results, such as collection, processing, representation, analysis, and comparison to sources.

- Drawing conclusions.

- Presentation of the inquiry process and its products.

- Assessment of the inquiry and reflection.

7 R. Gott, S. Duggan, Investigative Work in the Science Curriculum; R. Roberts, Procedural understanding in biology, p. 113-117; R. Roberts, R. Gott, Procedural understanding: Its place in the biology curriculum, School Science Reviews, 1999, 81, p. 19.

8 A. Ben David, The process of scientific inquiry in the classroom: From theory to practice, Eureka, 2012, 33, p. 1-19. (Hebrew)

9 Pedagogical Secretary, The Assimilation of Inquiry in the Educational System in Israel.

${ }^{10} \mathrm{~J}$. Krajcik et al., Instructional, curricular, and technological supports for inquiry in science classrooms, [in:] Inquiring into Inquiry Learning and Teaching in Science, Eds. J. Minstrell, E.H. Van Zee, Washington, DC 2000, p. 283-315; E. Etkina, A. Van Heuvelen, Investigative Science Learning Environment - A science process approach to learning physics, [in:] PER-based Reforms in Calculus-Based Physics, Eds. E.F. Redish, P. Cooney, College Park, MD 2007, p. 1-48; A. Hofstein et al., Learning through inquiry in the chemistry laboratory. (Hebrew); A. Ben David, The process of scientific inquiry in the classroom, p. 1-19. (Hebrew) 
The aforementioned list of components is a basic and general list and it is possible, of course, to add elements. The inquiry can be a whole process, which includes all the components, or a modular process that enables the focus on individual parts of the full inquiry. ${ }^{11}$

These components do not necessarily express chronological order. In actuality, the students in a research physics program undergo an inquiry process that is not necessarily linear but is composed of stages with reciprocal interaction and the transition between them is network-like. The formation of the inquiry question, for example, is a dynamic process and its formulation can change with the advance in the work stages. Often the students return to certain components, skip a component, and perhaps reach it at a later stage (or not at all). There are also components that strongly depend on what is done beforehand and cannot exist if a previous component is not done. ${ }^{12}$

\section{The inquiry process is a dynamic process}

The inquiry process is a dynamic process

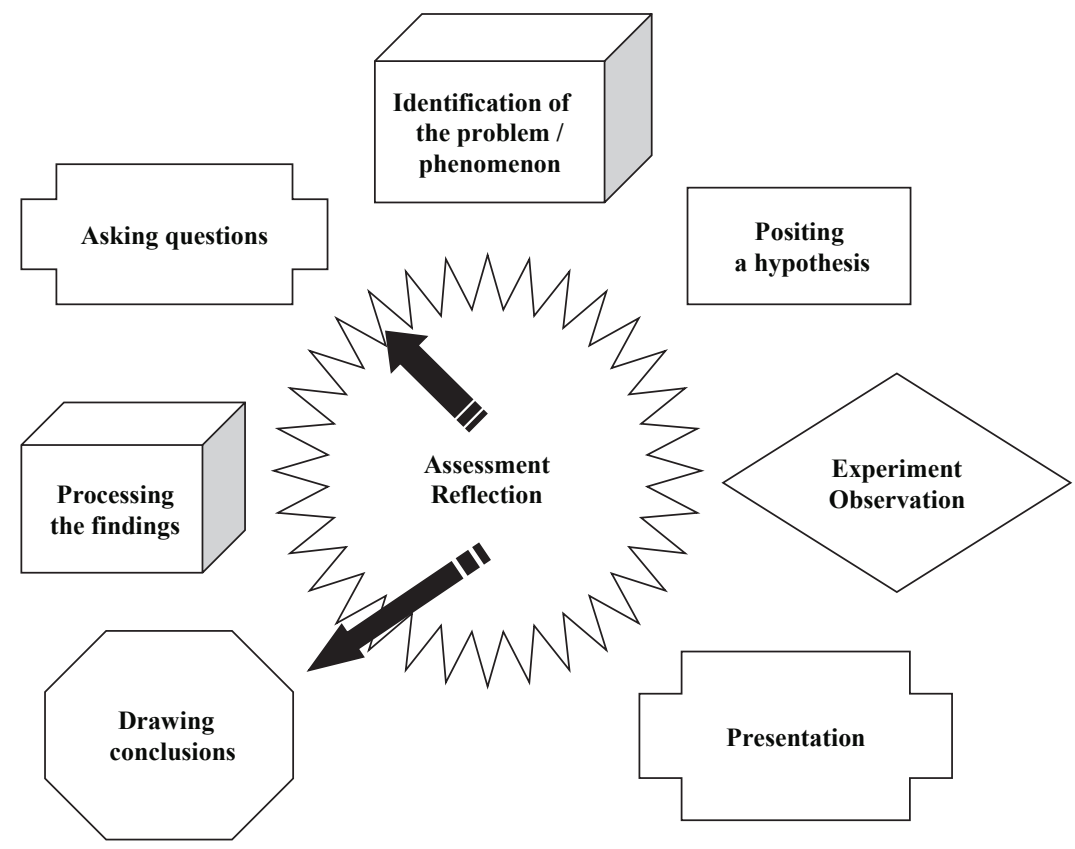

${ }^{11}$ Pedagogical Secretary, The Assimilation of Inquiry in the Educational System in Israel; S. Rozenfeld, A. Flik, Learning through Projects (Teacher Guide), Rechovot 2002. (Hebrew)

${ }^{12}$ J. Krajcik et al., Instructional, curricular, and technological supports, p. 283-315; E. Etkina, A. Van Heuvelen, Investigative Science Learning Environment, p. 1-48. 
It is important to allow the students to experience the performance of an entire process of scientific inquiry, from the phenomenon or the problem, through the conclusions and the discussion of them as well as the new questions for further research, to the process of assessment and reflection. ${ }^{13}$ Partial teaching of the inquiry components does not allow the student to acquire an overall picture of the ideas at the basis of the inquiry. ${ }^{14}$

\section{Learning through Inquiry in the Fieldof the Teaching of Physics in the High School in Israel}

Learning through inquiry is at its beginning in the State of Israel and mainly in the knowledge realm of physics. For all the laboratory lessons in physics of a certain class in the high school in Israel there is a chance of about $95 \%$ that all the laboratory activities will be conducted in the traditional teaching approach (the datum was given by the subject supervisor of physics on the basis of the data of Administration and Information and Communications Technology and Information Systems in the Ministry of Education). Only about $5 \%$ of the laboratory lessons in physics combine activities based on the inquiry approach, since most of the teachers who teach physics in the high school are not experts in teaching using inquiry ${ }^{15}$. One of the conclusions from a recent research ${ }^{16}$ is that physics teachers acknowledge the importance of the promotion of inquiry skills in the classroom but most do not engage in it routinely. To adjust the laboratory teaching to the role of the experiment in the real world of physics, the teachers must integrate an inquiry based teaching approach. Since in the inquiry laboratories there is the potential to promote meaningful learning among the students, to increase the depth of their understanding of the scientific concepts and the understanding of the nature of science. ${ }^{17}$

\section{The Rationale of the 'Inquiry Physics' Program}

The 'Inquiry Physics' Program is a new official program that has been approved by the Subject Committee. The program aims to improve the different initiatives in Israel for the integration of inquiry in the teaching of physics. The goal is to provide these initiatives an appropriate place in the teaching of

${ }^{13}$ S. Rozenfeld, A. Flik, Learning through Projects (Teacher Guide). (Hebrew)

${ }^{14}$ R. Roberts, Procedural understanding in biology, p. 113-117.

${ }_{15}$ Z. Kapach, From Laboratory Teaching in the Cookbook Approach to Laboratory Teaching. (Hebrew)

${ }^{16}$ Ibidem.

${ }^{17}$ E. Etkina, A. Van Heuvelen, D. Mills, Role of experiments in physics - A process approach, The Physics Teacher, 2002, 40, p. 351-355. 
physics and to encourage the students to produce Inquiry Project of a high level. The vision of this project that, the students will be able to solve problems with tools and language from the field of physics and will experiment in practical research (without knowing the anticipated answer).

Although the student has the possibility of doing an 'inquiry project' in the framework of the physics studies, when this project is of a limited scope, it becomes clear that this is not satisfactory according to the students, the teachers, and the entire educational system. The great effort invested in the

\section{It is important to experience an entire inquiry process!}

Inquiry Project does not produce a real return in the student's high school matriculation certificate and in the recognition of the institutions of higher education. Consequently, it is harder to recruit students to perform projects and engage in scientific inquiry. Therefore, the Physics Supervisor Coordinator of the Ministry of Education, Dr. Arica, along with the Steering Staff, formulated a program called 'Inquiry Physics' at the scope of five units of study (in addition to the five units that exist in the studies of physics, the highest level of physics studies in the high school in Israel). So the students will receive a more significant recompense for their research work.

Additionally, the 'Inquiry Physics' Program is an opportunity to produce return not only on the level of the student but also on the level of the teacher and society at large. On the level of the teacher, it can bring a new spirit into the teaching of the subject. Physics teachers develop during their career in pedagogical terms but in scientific terms they stay in place, since they repeat the same basic chapters of content, with a syllabus that has barely developed over many years. The possibility of integrating research may open for them periodically a window into additional chapters of physics, into real engagement in physics. Furthermore, the guidance of the research will cause the teachers to diversify their ways of instruction.

For the teachers, leading inquiry project will intensify them as physicists, strengthen their connection with the students and will promote the traditional instruction in all of their frames of work. Leading an inquiry project will contribute an enhancement of positive feelings towards the teaching profession and will strengthen the teacher's status.

On the level of society, the program will train graduates who underwent a significant experience of independent learning and research and thus will instill in them the tools necessary for integration into the advanced society of 
the 21st century. ${ }^{18}$ Since scientific knowledge and scientific thinking are relevant and even necessary for everyday life in order to be able to understand and analyze information received for different sources, and in order to solve problems in the "real world". ${ }^{19}$

\section{The Goals of the Program}

The 'Inquiry Physics' Program for students is a unique and prestigious program, which opens for the students a window to the world of scientific research. This is for the raising of interest of the students in physics, for the inculcation of the research knowledge for more students, for the cultivating of the learners' responsibility, as well the encouragement of creativity, initiative, and imagination of the students. It enables the students not only to recognize the discipline but also to understand what to do with it in actuality. It enables them to structure their learning, at a pace suitable to them, with greater depth of understanding. It provides a solution for students who are missed by the learning style accepted in the teaching of physics. It develops among them abilities of independent learning, coping with problems, analysis of complex problems, and creation of solutions that will allow them to act under conditions of uncertainty, which are the clear characteristic of the present and future eras. ${ }^{20}$

\section{What Do Students Learn in "Inquiry Physics?}

Students in "Inquiry physics" program will experience physical issues by using the inquiry method. Inquiry learning, in the field of physics, requires expertise in the field of content and an understanding of physical processes and physical principles. Simultaneously with other skills such as units of physics and mathematics unique according to the subject of the inquiry; inquiry method and research statistics; scientific writing, reading and analyzing academic articles; advanced computer skills; the history of physics emphasizing researches, experiments, discoveries and inventions; and more. In this way, the students will be able to study intensively subjects from the school program, to learn new subjects (outside of the school program) and to develop a variety of skills acquired by inquiry. The implementation of inquiry project invites the fostering of learning skills in the field of content and in the field of scientific research. Additionally, it connects the profession of physicist to the

${ }_{18}$ Tz. Arika, Z. Krakover, Steering Committee, Draft Letter to the Subject Committee before the Discussion on the Research Physics Program, 2016.

${ }^{19}$ N.W. Feinstein, S. Allen, E. Jenkins, Outside the pipeline: Reimagining science education for nonscientists, Science, 2013, 340, p. 314-317.

${ }^{20}$ Supervisor Coordinator, Letter to School Principals on the Dissemination of the 'Inquiry Physics' Program, Ministry of Education 2016. 
modern cultural space and permits integration between the field of physics and other fields. The subject of the inquiry should be actual and on the forefront of research in the world. ${ }^{21}$

\section{The Target Audience of the Program}

The target audience of the program consists of students with motivation, who learn in the physics program on the level of five units of study in the high school (highest level of physics studies in the high school in Israel). The required scholastic level emphasizes cognitive skills as well as theoretical and applied knowledge on the highest level. The research in physics requires a significant background in physics, and therefore this program cannot come in place of the study of physics at the level of five units (highest level of physics studies), but is in addition to it, at the level of another five units. Parallel learning of physics at the level of five units is a necessary condition for participation in the 'Inquiry Physics' program ${ }^{22}$.

\section{The Learning Environment of the Program and Its Time Frame}

Today, 'Inquiry Physics' program, in the Davidson Institute of Science Education, is proposed for students as a program that is 'outside of the school', as a program that operates in the afternoon outside of the school wal1s. Since in every class there are only a few students who are interested in performing physics inquiry, it was necessary to collect small groups of students from a number of schools. Therefore, students who chose to learn in the framework of 'Inquiry Physics' in the Davidson Institute come from different schools and become a mixed group, for a total of twenty students.

The physical environment in which the students are found is a technology-intensive laboratory in the Davidson Institute, rich in sophisticated laboratory equipment. As well as laboratory staff, acting in full cooperation with the facilitators and students. The aim is to allow students to conduct experiments / build projects that are complex relative to the regular laboratory in the high school. The learning environment of the program encourages diverse learning methods such as independent learning, active learning, cooperative learning, peer learning, and online and/or computerized learning.

The 'Inquiry Physics' Program in the Davidson Institute began to be implemented in 2015 for tenth grade students and they will continue with it until the twelfth grade. The framework of the program is for three years: in the tenth grade, four hours every two weeks, and in the eleventh and twelfth grades four hours a week.

\footnotetext{
${ }^{21}$ Tz. Arika, Z. Krakover, Steering Committee.

22 Supervisor Coordinator, Letter to School Principals.
} 


\section{The Instruction in the Program}

The main work of the students is supported by instructors who expert in teaching through inquiry. It should be noted that the program instructors are not the teachers of the students in the school. The fact that most of the teachers who teach physics in the high school are not expert in teaching through inquiry dictated the need for the support of the expert teachers. The program instructors implement an innovative program of the Department for the Teaching of the Sciences for many years, including the Inquiry Physics Program.

The guidance is focused on the student - it is for a pair of students or small groups. In the framework of the program, the students receive opportunities for the performance of physics inquiry at different levels of guidance: structured inquiry, guided inquiry, open inquiry, when the differences between the levels are related to the student's degree of independence and the teacher's degree of involvement when the inquiry is performed. ${ }^{23}$ When open inquiry is the highest level of inquiry achieved. In this level, the students have the utmost independence in all the inquiry stages. Therefore, this is the approach that reflects to the greatest possible extent the scientist's work. In essence, here the student experiences real inquiry work ${ }^{24}$.

The following figure ${ }^{25}$ presents the relationship between the teacher's instruction and the student's independence, between structured inquiry and open inquiry.

The instruction of the teacher

The independence of the student

Structured Inquiry

Open Inquiry

${ }^{23}$ L. Martin-Hansen, Defining inquiry: Exploring the many types of inquiry in the science classroom, The Science Teacher, 2002, 69(2), p. 34-37; National Research Council, National Science Education Standards.

${ }^{24}$ L. Martin-Hansen, Defining inquiry, p. 34-37; D.S. Domin, A review of laboratory instruction styles, Journal of Chemical Education, 1999, 76, p. 543-547.

${ }^{25}$ Z. Kapach, From Laboratory Teaching in the Cookbook Approach to Laboratory Teaching. (Hebrew); A. Ben David, The process of scientific inquiry in the classroom, p. 1-19. (Hebrew); L. Martin-Hansen, Defining inquiry, p. 34-37. 
Ben David ${ }^{26}$ proposes that one of the ways to relieve load entailed in the inquiry process is to avoid the scientific inquiry process as a constellation and to adopt the teaching model that she calls the 'zipper model'. This teaching model proposes to move gradually on the scale between structured inquiry and open inquiry. In other words, to begin with the 'closed zipper', the structured inquiry task, in which the students work according to the teacher's directives, which lead to the pre-known discovery and are required to present it. Gradually 'open the zipper', each time with the requirement of a new inquiry skill, until the open inquiry task, in which the students implement all the inquiry skills themselves. The facilitators of this program work with Dr. Kapach, ${ }^{27}$ who also recommends incorporating the inquiry in the laboratory through activities in the steadily advancing levels of inquiry, from 'closed' laboratory activity through 'semi-closed' activity to open activity. In the research literature, there are additional recommendations according to which it is necessary to combine inquiry at a variety of levels, when together they build the process of learning through inquiry. ${ }^{28}$

\section{Assessment of Research in the Framework of 'Inquiry Physics' Program}

The teaching and learning in the inquiry method need to include diverse tools of assessment suited to knowledge, skills, and practices to which the learners were exposed during their work. ${ }^{29}$ The tasks in "Inquiry Physics" program that the students will submit and the ways of evaluating them will be diverse throughout all three years of the studies. The students will submit their research work and their research project file (in which there will be all the products, such as laboratory reports, portfolio file), which constitutes a main and important component. The approach to assessment that should be adopted in learning through inquiry is the approach that combines formative assessment (also called assessment for learning) and summative assessment. The main goals of formative assessment are to identify specific scholastic needs so as to address them in the continuation of the learning, to assess the gap between the existing situation and the desired situation, and to adopt suitable steps for the reduction of the gap and the evaluation of effectiveness.

\footnotetext{
${ }^{26}$ A. Ben David, The process of scientific inquiry in the classroom, p. 1-19, 2012. (Hebrew)

27 Z. Kapach, From Laboratory Teaching in the Cookbook Approach to Laboratory Teaching. (Hebrew)

${ }^{28}$ L. Martin-Hansen, Defining inquiry, p. 34-37.; J.J. Schwab, The teaching of science as inquiry, [in:] The Teaching of Science, Eds. J.J. Schwab, P.E. Brandweine, Cambridge, Mass 1962.

${ }_{29}$ Pedagogical Secretary, The Assimilation of Inquiry in the Educational System in Israel; W. Harlen, Enhancing inquiry through formative assessment. San Francisco: Exploratorium 2003, http:/ / citeseerx.ist.psu.edu/viewdoc/ download?doi=10.1.1.128.5260\&rep=rep1\&type=pdf; R. Sadler, Formative assessment and the design of instructional systems, Instructional Science, 1989, 18, p. 119-144.
} 
Therefore, formative assessment is assessment incorporated in learning. In contrast, the main goal of summative assessment is to obtain a general assessment on the level of the student's achievements at the end of the learning process. ${ }^{30}$ This assessment, which focuses on grades and responsibility, has to be respected in many contexts but does not appropriately serve the student's immediate learning needs. ${ }^{31}$

The assessment of the inquiry work in all its stages, by its very nature, cannot be satisfied with the measurement of the final products and cannot be performed in a one-time way at the end of the learning process. The assessment of the inquiry work needs to be performed throughout the entire work process and to follow up after the scholastic process that the student experienced. ${ }^{32}$ This is expressed in the display of abilities and competencies acquired/ strengthened during the inquiry, in the active understanding of the scientific knowledge and its connection to the problem, in the insightful achievement of the inquiry process and result. It must be composed of formative assessment, which will contribute to the development and improvement of the work, and summative assessment of the final work..$^{33}$ It is worth noting that the students are also involved in the assessment processes. ${ }^{34}$

\section{Summary}

According to the National Research Council ${ }^{35}$ inquiry in science addresses a variety of ways in which a scientist learns about the essence of nature and the ways in which he offers explanations on the basis of evidence that he collects during his work. Learning through inquiry includes activities through which the students develop knowledge and understanding about scientific ideas and about the way in which the scientist learns about the essence of

${ }^{30}$ M. Birenboim, Alternatives in the Assessment of Achievements, Tel Aviv 1997. (Hebrew); M. Birenboim, Assessment for learning and characteristics of a school professional community and class culture that empower it, [in:] Assessment, Jewish Education, and History of Education: A Collection in the Memory of Professor Aryeh Levi, ZL, Ed. Y. Keshti, Tel Aviv 2009, p. 77-144; R. Sadler, Formative assessment, p. 119-144.

31 J.B. Baron, Performance assessment: Blurring the edges among assessment, curriculum, and instruction, [in:] Assessment in the Service of Instruction: This Year in School Science 1990, Eds. A.B. Champagne, B.E. Lovitts, B.J. Calinger, Washington, DC 1990.

${ }^{32}$ W. Harlen, Enhancing inquiry through formative assessment. San Francisco: Exploratorium 2003, http:/ / citeseerx.ist.psu.edu/viewdoc/download?doi=10.1.1.128.5260\&rep=rep1\&type=pdf

${ }_{33}$ M. Birenboim, Alternatives in the Assessment of Achievements. (Hebrew); W. Harlen, Enhancing inquiry through formative assessment. San Francisco: Exploratorium 2003, http:/ / citeseerx.ist. psu.edu/viewdoc/download?doi=10.1.1.128.5260\&rep=rep1\&type=pdf,"

34 A. Zohar, Inquiry learning, high thinking skills, p. 57-84. (Hebrew)

35 National Research Council, National Science Education Standards. 
nature. Schwab ${ }^{36}$ maintains that, 'science as inquiry' should be taught through inquiry. In this way, the student experiences the search for and definition of the problem and copes with the problem through the search for ways to solve it, through the planning and performance of an experiment. Learning through inquiry allows the student to experience 'being a scientist'. In this way, he learns about himself and examines his attitude towards science. ${ }^{37}$

Inquiry learning is an educational approach with the goal of developing an independent learner. The principle in this teaching is that the students are not presented the information intended for the learning in an explicit manner. Instead, the teacher creates an intellectual and social atmosphere, in the framework of which the learner has responsibility and control over the learning process. In this way, the students plan by themselves how to identify and achieve information, collect data, phrase by themselves the questions and the rules and laws according to which they will act, and determine themselves their pace of progress and the ways of learning. ${ }^{38}$ For the students to cope with this complexity, the teacher's help is required. ${ }^{39}$ Learning skills do not develop spontaneously for most students. They should be taught explicitly. ${ }^{40}$ The teacher-instructor must examine the knowledge required of the students in every stage of the work and decide (in light of what is required and in light of their age, experience, and learning goals) which concepts and skills should be inculcated in them and the degree of support and accompaniment of the students. When the degree of instruction of the teacher changes from time to time, ranging from full instruction of the teacher at one end to the non-instruction of the teacher at the other end, when in the middle there is a middle situation in which the teacher helps the student research by himself. ${ }^{41}$

Educators in the teaching of the sciences in Israel and around the world ${ }^{42}$ recommend combining an inquiry-based approach in the teaching of the sciences, since in inquiry learning it is possible to aspire to authenticity in the scientific work, to develop high order thinking skills and skills for independent work and to the reinforcement of the disciplinary knowledge. In addition to these

${ }^{36}$ J.J. Schwab, The teaching of science as inquiry.

${ }^{37}$ Ibidem; J. Dewey, Logic: The Theory of Inquiry, New York 1938.

${ }^{38}$ N. Hativa, Processes of Teaching in the Classroom, Tel Aviv 2003. (Hebrew)

${ }^{39}$ C.A. Chinn, B.A. Malhotra, Epistemologically authentic inquiry in schools: A theoretical framework for evaluating inquiry tasks, Science Education, 2002, 86(2), p. 175-218.

${ }^{40}$ A. Zohar, F. Nemet, Fostering students' knowledge and argumentation skills through dilemmas in human genetics, Journal of Research in Science Teaching, 2002, 39, p. 3-62.

${ }^{41}$ E. Dreyfus, Strategies Appropriate for Teaching in the Laboratory - Waves in the Teaching of the Sciences: Booklet for Biology Teachers, 1995, 142, p. 6-22.

${ }^{42}$ Z. Kapach, From Laboratory Teaching in the Cookbook Approach to Laboratory Teaching. (Hebrew); A. Hofstein et al., Learning through inquiry in the chemistry laboratory. (Hebrew); A. Zohar, Inquiry learning, high thinking skills, p. 57-84. (Hebrew); L. Martin-Hansen, Defining inquiry, p. 34-37; J. Krajcik et al., Instructional, curricular, and technological supports, p. 283-315. 
advantages, the desire to inculcate in the graduates of the physics study the tools necessary for their integration into the advanced society of the 21st century has dictated the need to build a unique program called 'Inquiry Physics', with the support of the developers and expert teachers. In the inquiry physics environment, there is the potential for the promotion of the students' learning and for the increase of the depth of their understanding of the scientific concepts and understanding of the nature of science and to transform the student into an independent inquirer possessed of initiative.

This program enables the students to attempt inquiry skills in different types of activities, which offer a variety of levels of research. Thus, the students can learn and research in an in-depth manner topics from the curriculum, get to know new topics (beyond the curriculum), and develop a variety of skills acquired through inquiry. The aim is to promote the assimilation of inquiry learning in the teaching of physics and in this way to reduce the gap created between the declarations about the importance of inquiry teaching and the implementation of the teaching in actuality.

It should be said that this is a program that is at its beginning, which does not have an internal tradition, and that there may be difficulties in the continuation. The tension between the extensive engagement in the way of inquiry and the difficulties entailed by the implementation of this way require therefore in-depth clarification. ${ }^{43}$ Therefore, it is necessary to investigate this 'Inquiry Physics' program, to describe the process that the students will achieve through the 'Inquiry Physics' program, as well as to examine the influence of experience in the inquiry physics environment on their scientific knowledge in physics, their understanding of scientific concepts, their development inquiry skills and their perceptions of the students towards the scientific researcher and the process of scientific research.

\section{BIBLIOGRAPHY}

Arika Tz., Krakover Z., Steering Committee, Draft Letter to the Subject Committee before the Discussion on the Research Physics Program, 2016.

Baron J.B., Performance assessment: Blurring the edges among assessment, curriculum, and instruction, [in:] Assessment in the Service of Instruction: This Year in School Science 1990, Eds. A.B. Champagne, B.E. Lovitts, B.J. Calinger, American Association for the Advancement of Science, Washington, DC 1990.

Ben David A., The process of scientific inquiry in the classroom: From theory to practice, Eureka, 2012, 33. (Hebrew)

Birenboim M., Alternatives in the Assessment of Achievements, Ramot Press, Tel Aviv 1997. (Hebrew)

${ }^{43}$ A. Zohar, Inquiry learning, high thinking skills, p. 57-84. (Hebrew) 
Birenboim M., Assessment for learning and characteristics of a school professional community and class culture that empower it, [in:] Assessment, Jewish Education, and History of Education: A Collection in the Memory of Professor Aryeh Levi, ZL, Ed. Y. Keshti, Ramot, Tel Aviv 2009.

Chinn C.A., Malhotra B.A., Epistemologically authentic inquiry in schools: A theoretical framework for evaluating inquiry tasks, Science Education, 2002, 86(2).

Dewey J., Logic: The Theory of Inquiry, Holt, Rinehart and Winston, New York 1938.

Domin D.S., A review of laboratory instruction styles, Journal of Chemical Education, 1999, 76.

Dreyfus E., Strategies Appropriate for Teaching in the Laboratory - Waves in the Teaching of the Sciences: Booklet for Biology Teachers, 1995, 142.

Etkina E., Van Heuvelen A., Investigative Science Learning Environment - A science process approach to learning physics, [in:] PER-based Reforms in Calculus-Based Physics, Eds. E.F. Redish, P. Cooney, American Association of Physics Teachers, College Park, MD 2007.

Etkina E., Van Heuvelen A., Mills D., Role of experiments in physics - A process approach, The Physics Teacher, 2002, 40.

Feinstein N.W., Allen S., Jenkins E., Outside the pipeline: Reimagining science education for nonscientists, Science, 2013, 340.

Gott R., Duggan S., Investigative Work in the Science Curriculum, Open University Press, Buckingham 1995.

Harlen W., Enhancing inquiry through formative assessment. San Francisco: Exploratorium 2003, http:// citeseerx.ist.psu.edu/viewdoc/download?doi=10.1.1.128.5260\&rep=rep1\&type=pdf;

Hativa N., Processes of Teaching in the Classroom, Academic Press for the Development of the Teaching Faculty, Tel Aviv 2003. (Hebrew)

Hofstein A., Shor R., Kipnis M., Levy Nachum T., Learning through inquiry in the chemistry laboratory, [in:] Learning through Inquiry, Ed. A. Zohar, Magnes Press, Jerusalem 2007. (Hebrew)

Kapach Z., From Laboratory Teaching in the Cookbook Approach to Laboratory Teaching in the Inquiry-Based Approach in the Studies of Physics in the High School: Professional Development of Teachers, Ph.D. Dissertation, Weizmann Institute of Science, Rechovot 2015. (Hebrew);

Krajcik J., Blumenfeld P., Marx R.W., Soloway E., Instructional, curricular, and technological supports for inquiry in science classrooms, [in:] Inquiring into Inquiry Learning and Teaching in Science, Eds. J. Minstrell, E.H. Van Zee, American Association for the Advancement of Science, Washington, DC 2000.

Martin-Hansen L., Defining inquiry: Exploring the many types of inquiry in the science classroom, The Science Teacher, 2002, 69(2).

National Research Council, National Science Education Standards, National Academy Press, Washington, DC 1996.

Pedagogical Secretary, The Assimilation of Inquiry in the Educational System in Israel, The Ministry of Education, Jerusalem 2008, (Hebrew), http://cms.education.gov.il/EducationCMS/Units/Mazkirut_Pedagogit/OfekPedagogi/Lemida_Cheker/

Roberts R., Procedural understanding in biology: "Thinking behind the doing", Journal of Biological Education, 2001, 35(3).

Rozenfeld S., Flik A., Learning through Projects (Teacher Guide), Department for Teaching Sciences, Weizmann Institute for Science, Rechovot 2002. (Hebrew)

Sadler R., Formative assessment and the design of instructional systems, Instructional Science, 1989, 18. 
Schwab J.J., The teaching of science as inquiry, [in:] The Teaching of Science, Eds. J.J. Schwab, P.E. Brandweine, Harvard University Press, Cambridge, Mass 1962.

Supervisor Coordinator, Letter to School Principals on the Dissemination of the 'Inquiry Physics' Program, Ministry of Education 2016.

Zohar A., Inquiry learning, high thinking skills, and meta-cognition, [in:] Learning through Inquiry: A Continuous Challenge, Ed. A. Zohar, Magnes Press, Jerusalem 2007. (Hebrew) Zohar A., Nemet F., Fostering students' knowledge and argumentation skills through dilemmas in human genetics, Journal of Research in Science Teaching, 2002, 39. 